\title{
Examining Levels of Mathematics Teaching Anxiety of Pre-service Teachers
}

\author{
Enver TATAR $^{*} \quad$ Yılmaz ZENGİN ${ }^{* *}$ Türkan Berrin KAĞIZMANLI ${ }^{* * *}$
}

\begin{abstract}
Received: 16 April 2014
Accepted: 19 September 2015

ABSTRACT: This research was conducted in order to determine the levels of mathematics teaching anxiety of preservice mathematics teachers. Survey design was used in the research. The sample of the research was composed of 475 pre-service mathematics teachers who study in the education faculty in a state university in Turkey. A personal information form and a mathematics teaching anxiety scale were used as a data collection tools in the research. The scale comprises 4 sub-dimensions: teaching anxiety caused by content knowledge, teaching anxiety caused by selfconfidence, teaching anxiety caused by attitude towards teaching mathematics and teaching anxiety caused by teaching knowledge. As a result of the research, it was determined that the levels of mathematics teaching anxiety of pre-service teachers are below the average score value. Accordingly, it was detected that there was a difference among the levels of mathematics teaching anxiety of pre-service teachers in terms of teaching anxiety caused by content knowledge sub-dimension and their general anxiety according to elementary undergraduate program and secondary undergraduate program. Moreover, it was observed that there was a difference according to class levels among the mathematics teaching anxiety of pre-service mathematics teachers' mathematics teaching anxiety in terms of the sub-dimension of teaching knowledge. Lastly, it was determined that the anxiety of mathematics teaching of pre-service teachers did not differ in terms of gender.
\end{abstract}

Keywords: mathematics teaching anxiety, mathematics teaching, anxiety, pre-service mathematics teachers

\section{Extended Abstract}

Purpose and Significance: Anxiety of students ranks first among the most important problems that are experienced in the field of mathematics (Baloğlu, 2001). Dreger and Aiken (1957) defined the mathematics anxiety as a syndrome of the emotional reactions that are shown towards arithmetic and mathematics. This anxiety is connected with a number of problems and concerns of students in learning mathematics ( $\mathrm{Ma} \mathrm{\&} \mathrm{Xu}$, 2004). According to Gresham (2010) mathematics anxiety is described as both an emotional feature and a cognitive feature in the nature of the individuals who experience learning problems. The reasons for mathematics anxiety are classified in three different groups, namely as situational, personalistic and personal reasons (Byrd, 1982). It is observed that the situational reasons cause the anxiety resulting from the structure of mathematics and the methods used in teaching of mathematics; the personalistic reasons are the ones that are about the psychological and emotional

\footnotetext{
* Corresponding Author: Assoc. Prof. Dr., Atatürk University, Erzurum, Turkey, entatar@gmail.com

*** Res. Assist. Dr., Dicle University, Diyarbakır, Turkey, yilmazzengin@outlook.com

*** Assist. Prof. Dr., Giresun University, Giresun, Turkey, turkanberrin@gmail.com
}

\section{Citation Information}

Tatar, E., Zengin, Y., \& Kağızmanlı, T. B. (2016). Öğretmen adaylarının matematik öğretmeye yönelik kayg1 düzeylerinin incelenmesi. Kuramsal Eğitimbilim Dergisi [Journal of Theoretical Educational Science], 9(1), 38-56. 
characters of students; and the personal reasons are the factors such as gender, age, ethnic origin, study field, academic class and socioeconomic level (Baloğlu, 2001; Peker, 2006). In view of these reasons, mathematics anxiety and mathematics teaching anxiety constitute another point that is researched by the educators. Mathematics teaching anxiety is defined as the feeling of stress and anxiety that is experienced by teachers in the teaching of mathematical concepts, theorems, formulas or problem solving (Peker, 2006). In the conducted researches, it is observed that the expectations about effectively using mathematics are increasing day by day as a result of the fact that mathematics is seen in every field of our lives. Many educators, who raise teachers, believe that still the main objective of the mathematics curriculums, which are prepared for the pre-service teachers, is to maintain a positive attitude towards mathematics (Battista, 1986). Brady and Bowd (2005) emphasized that the mathematics teaching, which is taken by pre-service teachers, does not prepare them to trust themselves while teaching a concept, and this condition turns into a potential that may repeat itself in their students. However, the obtained results show that the teachers are not trained enough on mathematics anxiety and mathematics teaching anxiety. This research was conducted in order to determine the mathematics teaching anxiety levels of pre-service mathematics teachers.

Method: Survey design, which is among quantitative approaches, was used in the research (McMillan \& Schumacher, 2010). The sample of the research was composed of 475 pre-service mathematics teachers. A personal information form and a mathematics teaching anxiety scale (Peker, 2006), which was composed of "teaching anxiety caused by content knowledge”, "teaching anxiety caused by self-confidence”, "teaching anxiety caused by attitude towards teaching mathematics" and "teaching anxiety caused by teaching knowledge" sub-dimensions, were used in the research. The basic descriptive statistics, independent sample t-test, ANOVA, Mann-Whitney U test and KruskalWallis test were used in the analysis of data.

Results and Recommendations: The findings obtained in the research were studied as the distribution of teaching anxiety caused by content knowledge of pre-service teachers, their teaching anxiety caused by self-confidence, their teaching anxiety caused by attitude towards teaching mathematics, their teaching anxiety caused by teaching knowledge and their general mathematics teaching anxiety scores and the distribution of these scores in terms of undergraduate program, class levels and gender. In view of the research, it was determined that the levels of mathematics teaching anxiety of preservice teachers are below the average. Accordingly, it was detected that there was a difference among the levels of mathematics teaching anxiety of pre-service teachers in terms of teaching anxiety caused by content knowledge sub-dimension and their general teaching anxiety according to elementary undergraduate program and secondary undergraduate program. Moreover, it was observed that there was a difference according to class levels among the mathematics teaching anxiety of both pre-service 
elementary mathematics teachers and pre-service secondary mathematics teachers' mathematics teaching anxiety in terms of the sub-dimension of teaching anxiety caused by teaching knowledge. Lastly, it was determined that the mathematics teaching anxiety of pre-service teachers did not differ in terms of gender.

According to the findings obtained in the research it is considered that the teaching applications of pre-service teachers can be increased in the undergraduate period and hence their teaching anxiety can be reduced. Furthermore, a suggestion can be made on researching the reasons for teaching anxiety in more detail in the qualitative researches that will be conducted henceforth. Correlational researches can be made by working with large samples in different universities. 


\title{
Öğretmen Adaylarının Matematik Öğretmeye Yönelik Kaygı Düzeylerinin İncelenmesi
}

\author{
Enver TATAR $^{*} \quad$ Yılmaz ZENGİN ${ }^{* *}$ Türkan Berrin KAĞIZMANLI ${ }^{* * *}$
}

Makale Gönderme Tarihi: 16 Nisan 2014

Makale Kabul Tarihi: 19 Eylül 2015

\begin{abstract}
ÖZ: Bu araştırma, matematik öğretmeni adaylarının matematik öğretme kaygı düzeylerini belirlemek amacıyla yapılmıştır. Araştırmada nicel araştırma yaklaşımlarından tarama yöntemi kullanılmıştır. Araştırma Türkiye'de bulunan bir üniversitenin eğitim fakültesindeki 475 matematik öğretmeni adayı ile gerçekleştirilmiştir. Veri toplama aracı olarak kişisel bilgi formu ve matematik öğretmeye yönelik kaygı ölçeği kullanılmıştır. Ölçek; alan bilgisi, öz güven, matematiği öğretmeye yönelik tutum ve alan eğitimi bilgisinden kaynaklanan öğretme kaygısı olmak üzere 4 alt boyuttan oluşmuştur. Araştırma sonucunda, öğretmen adaylarının matematiği öğretmeye yönelik kaygı düzeylerinin ortalama puan değerinin altında olduğu belirlenmiştir. Öğretmen adaylarının matematiği öğretmeye yönelik kaygı düzeylerinde; öğrenim görülen lisans programına göre alan bilgisi alt boyutu ve genel kaygıları açısından fark olduğu tespit edilmiştir. Ayrıca matematik öğretmeni adaylarının matematiği öğretmeye yönelik kaygılarında alan eğitimi bilgisi alt boyutu açısından sınıf düzeyine göre fark olduğu görülmüştür. Son olarak öğretmen adaylarının matematiği öğretmeye yönelik kaygılarının cinsiyete göre farklılık göstermediği belirlenmiştir.
\end{abstract}

Anahtar kelimeler: matematik öğretme kaygısı, matematik öğretimi, kaygı, matematik öğretmeni adayı

\section{Giriş}

Matematik alanında yaşanan en önemli problemlerin başında öğrencilerin yaşadıkları kaygı gelmektedir (Baloğlu, 2001). Matematik kaygısı, öğrencinin matematik problemlerini çözmesi beklendiğinde ya da gerektiğinde mantık dış1 duygusal tepkileri göstermesi ile oluşmaktadır (Aydın, 2011) ve son y1llarda dikkat çeken yaygın tutum ve duygusal faktörlerden biri olarak kabul edilmektedir (Baloğlu \& Koçak, 2006). Dreger ve Aiken (1957), matematik kaygısını; aritmetik ve matematiğe karşı gösterilen duygusal tepkilerin bir sendromu olarak tanımlamıştır. Bu kaygı öğrencilerin matematik öğrenmelerindeki bir dizi problem ve endişe ile ilişkilidir (Ma \& $\mathrm{Xu}, 2004)$. Matematik kaygısını, öğrenme problemleri yaşayan bireylerin bir özelliği olarak tanımlayan Gresham (2010), bu kaygının eğitimin her aşamasında sıklıkla karşılaşılan bir durum olduğunu belirtmiştir. Ayrıca öğrencilerde matematiksel öğrenmenin gerçekleşmesi için matematik kaygısını anlamanın ve tanımlamanın; bu kaygıyı önlemek veya azaltmak adına önemli bir adım olduğunu vurgulamıştır. Matematik dersine karşı kaygı duyulduğunda derse olan ilgi ve başarının azaldığı, matematik kaygısının öğrencilerin başarılarında büyük bir rol oynadığı ortaya konmuştur (Satake \& Amato, 1995; Sherman \& Wither, 2003; Zakaria \& Nordin, 2008).

Matematik kaygısının sebepleri; durumsal, kişiliksel ve kişisel sebepler olmak üzere üç farklı şekilde sınıflandırılmaktadır (Byrd, 1982). Durumsal sebeplerin matematĭgin yapısından ve matematik eğitiminde kullanılan yöntemlerden oluşan kaygı nedeni olduğu, kişiliksel sebeplerin öğrencinin psikolojik ve duygusal karakterlerini konu edinen sebepler olduğu ve kişisel sebeplerin ise cinsiyet, yaş, etnik köken,

\footnotetext{
* Sorumlu Yazar: Doç. Dr., Atatürk Üniversitesi, Erzurum, Türkiye, entatar@gmail.com

** Arş. Gör. Dr., Dicle Üniversitesi, Diyarbakır, Türkiye, yilmazzengin@outlook.com

**** Yrd. Doç. Dr., Giresun Üniversitesi, Giresun, Türkiye, turkanberrin@gmail.com
} 
akademik sınıf, sosyo-ekonomik düzey gibi etkenler olduğu görülmektedir (Baloğlu, 2001; Peker, 2006). Bu sebepler 1şığında matematik kaygısı ile birlikte matematik öğretme kaygısı eğitimcilerin araştırdığı bir diğer konudur. Araştırmalar, matematik öğretmenlerinin matematik kaygısı taşıdıklarını ve bu kaygıyı bilinçli veya bilinçaltı yollarla öğrencilerine transfer ettiklerini göstermektedir (Baloğlu, 2001). Matematik kaygı düzeyi yüksek olan öğretmenler daha çok geleneksel yöntemleri kullanmakta ve kavramların öğretimi yerine temel becerilerin öğretimi üzerine odaklanmaktadırlar (Gresham, 2010). Matematik öğretme kaygısi; öğretmenlerin matematiksel kavram, teorem, formül veya problem çözme öğretiminde yaşadıkları gerginlik ve kaygı duygusu olarak tanımlanmaktadır (Peker, 2006). Hadley ve Dorward (2011), öğretmenlerde yaşanan matematik kaygısının ilköğretim düzeyindeki matematiği öğretme kaygısına dönüştüğünde öğrencilerin matematiği öğrenme kabiliyetlerine olumsuz etki edebileceğini belirtmiştir. Öğrencilerde meydana gelebilecek olumsuz düşünceler onların matematik öğrenmelerinde olumsuz sonuçlar üretebilmektedir (Vinson, 2001). Buna göre öğretmenlerin matematikte olduğu kadar öğretmenlik mesleğinin birçok yönünde de yetkin olması istenmektedir (Peker, 2009a). Öğretmenlerden matematik kaygısının, kendi davranışlarından ve derslerde kullandıkları öğretme yaklaşımlarından kaynaklandığını ve sınıflarda yaşanan kötü deneyimlerin matematik kaygısını olumsuz yönde etkileyebileceğini bilerek öğrenciler yardım istediğinde sakin ve anlayışlı olmaları beklenmektedir (Bekdemir, 2010).

Matematik ve matematiksel pedagoji bilgi eksikliği ile matematiğe yönelik olumsuz tutum öğretmen adaylarının öğrenmelerini ve daha sonra kullanacakları etkili matematik öğretim yöntemlerini engelleyebilmektedir (Battista, 1986). Öğretmen adaylarının hem matematik kaygısına hem de öğretme kaygısına sahip oldukları yapılan araştırmalarda ortaya konmuştur (Bekdemir, 2007; Brown, Westenskow, \& MoyerPackenham, 2011; Elmas, 2010; Gresham, 2007; Liu, 2008; Peker, 2009b).

Uusimaki ve Nason (2004), ilköğretim öğretmen adaylarının matematik ile ilgili olumsuz inanış ve kaygılarının altında yatan sebepleri araştırmak üzere yaptıkları çalışmada katılımcıların büyük çoğunluğunun matematik kaygılarının ilköğretimde matematik öğrenirken yaşadıkları deneyimlerden kaynaklandığı sonucuna varmışlardır. Tooke ve Lindstrom (1998), ilköğretim matematik öğretmeni adaylarının matematik öğretim kursu öncesi ve sonrasında matematik kaygılarını incelediği araştırmalarında öğretmen adaylarının matematik kaygılarında bir değişikliğin olmadığını belirlemişlerdir. Gresham (2007), ise öğretmen adayları ile yaptığı çalışmada matematik öğretim kursu öncesi ve sonrasında öğretmen adaylarının matematik kaygılarını araştırmış ve kursun sonunda matematik kaygılarının azaldığını tespit etmiştir. Vinson (2001), farklı matematiksel materyal ve manipülatiflerin kullanılması ile öğretmen adaylarının matematik kaygı düzeylerinin değişimini araştırdığı çalışmasında öğretmen adaylarının kaygı düzeylerinde azalma olduğunu ve öğretmen eğitimi programlarında bu uygulamalara yer verilerek matematik kaygıları hakkında yorum yapılabileceğini belirlemiştir. Jackson (2008), öğretmen eğitimi kursunda ders alan öğretmen adaylarının matematik kaygılarının olup olmadığını ve bu kaygıların onların matematik 
öğretmelerini nasıl etkilediğini incelediği araştırmasında, öğretmen adaylarının matematik kaygılarının var olduğunu ve onların öğrenmelerini etkilediğini belirlemiştir. Bekdemir (2010), ilköğretim öğretmen adaylarının matematik kaygılarını incelediği araştırmasında öğretmen adaylarının matematik kaygılarının var olduğunu ve sorunlu sınıf deneyimlerinin matematik kaygıları üzerinde doğrudan etkili olduğunu belirlemiştir.

Peker (2008), matematiğin öğretileceği sınıf düzeyi azaldıkça öğretmen adaylarının öğretim kaygılarının arttığını belirlemiştir. Peker (2009b), öğretmen adaylarının öğrenme stillerine göre matematik öğretme kaygıları arasındaki farklılıkları incelediği araştırmasında faklı öğrenme stillerine sahip öğretmen adaylarının matematik öğretimine yönelik kaygılarının değiştiğini belirlemiştir. Peker ve Halat (2009), Webquest ve elektronik tablo ile oluşturulan matematiksel görselleştirme aktivitelerinin ilköğretim öğretmen adaylarının matematik öğretme kaygıları üzerindeki etkilerini araştırmışlardır. Araştırma sonucunda Webquest aktivitelerinin öğretmen adaylarının matematik öğretme kaygılarını azaltmada daha etkili olduğu görülmüştür. Elmas (2010), sınıf öğretmeni adaylarının matematik öğretmeye yönelik kaygı düzeylerini ve bu kaygıya neden olan faktörleri incelediği araştırmasında öğretmen adaylarının kaygı düzeylerinin genel olarak ortalamanın altında olduğu ve matematik öğretme kaygısına neden olan faktörlerin matematik kaygısı, staj, öz güven eksikliği, alan bilgisi eksikliği olduğunu tespit etmiştir. Haciomeroglu (2014), ilköğretim matematik öğretmeni adaylarının matematik kaygıları ve matematik öğretme kaygıları arasındaki ilişkiyi incelemiştir. Öğretmen adaylarının düşük düzeyde matematik kaygı ve öğretme kaygısına sahip olduklarını belirleyerek, matematik kaygısının matematik öğretme kaygısı üzerinde önemli derecede etkisi olduğunu tespit etmiştir.

Öğretme kaygısı üzerine yapılan çalışmaların genellikle ilköğretim öğretmen adaylarıyla yapıldığı (Elmas, 2010; Peker, 2009b; Peker, 2009c; Peker, 2015; Peker \& Halat, 2009; Peker, Halat, \& Mirasyedioğlu, 2010; Ural, 2015) görülmektedir. Bu çalışmalar arasında Elmas (2010), sınıf öğretmeni adaylarının, Peker (2009a), Peker (2009b) ve Peker \& Halat (2009), ilköğretim matematik öğretmeni adaylarının öğretme kaygılarını incelemişlerdir. İlköğretimde yaşanan öğretme kaygısının ilköğretim öğrencilerinin matematik öğrenmelerini etkilediği dikkate alındığında (Hadley \& Dorward, 2011) bu durumun ortaöğretimde de olabileceği karşımıza çıkmaktadır. Matematik öğretme kaygısı ile ilgili yapılan araştırmaların az olduğu göz önüne alındığında matematik öğretmeni adaylarının öğretme kaygı düzeylerinin araştırılması önem kazanmaktadır. Buna göre, iki farklı bölümün ele alınması öğretme kaygısının bölümler arasında da değerlendirmesinin yapılmasına imkân sağlaması açısından önemlidir. Çünkü farklı iki lisans programının ve farklı sınıf düzeyindeki öğretmen adaylarının öğretme kaygılarının ne düzeyde olacağı, bölümlerin öğretim programları açısından araştırmacılara katkı sağlayabilir. Öğretmen adaylarının matematik öğretme kaygılarını ele alan çalışmalarda kaygı düzeyleri alan bilgisinden, öz güvenden, matematiği öğretmeye yönelik tutumdan ve alan eğitiminden kaynaklanan kaygı alt boyutları açısından incelenmiştir (Elmas, 2010). Ayrıca öğretmen adaylarının 
matematiği öğretmeye yönelik kaygılarının cinsiyete göre farklılık gösterip göstermediğiyle ilgili çalışmalar yapılmıştır (Elmas, 2010; Peker, Halat, \& Mirasyedioğlu, 2010). Elmas (2010), çalışmasında kız öğretmen adaylarının matematik öğretme kaygı düzeylerinin erkek öğretmen adaylarına göre daha yüksek olduğunu tespit etmiştir. Ancak Peker, Halat ve Mirasyedioğlu (2010) ise araştırmalarında kız ve erkek öğretmen adaylarının matematik öğretme kaygı düzeyleri arasında anlamlı bir farklılık bulmamıştır. Elde edilen bu iki farklı sonuç 1şı̆̆ında ilköğretim ve ortaöğretim öğretmen adaylarının matematiği öğretmeye yönelik kaygı düzeylerinde cinsiyete göre anlamlı farklılık gösterip göstermediğine ilişkin daha geniş bir örneklemle yürütülen bu araştırmada elde edilen sonucun literatüre katkı sağlayabileceği düşünülmektedir.

Literatür incelendiğinde matematiğin hayatın her alanında görülmesinin bir sonucu olarak etkin bir şekilde kullanılmasıyla ilgili beklentilerin her geçen gün arttığı görülmektedir. Öğretmen yetiştiren birçok akademisyen, öğretmen adayları için hazırlanan matematik öğretim programlarının başlıca hedefinin, matematiğe yönelik tutumun olumlu olmasını sağlamak olduğuna inanmaktadır (Battista, 1986). Öğretim ortamına rehberlik eden öğretmenlerin lisans eğitimleri sırasında matematiğe yönelik tutumun olumlu yönde gelişmesi ve matematik kaygısı ile matematik öğretme kaygısının azaltılabilmesi için incelemeler yapılması önemlidir. Brady ve Bowd (2005), öğretmen adaylarının almış oldukları matematik eğitiminin, onları herhangi bir kavramı öğretirken kendilerine güven duymaları konusunda hazırlamadığını ve bunun bir döngü şeklinde onların da öğrencilerinde tekrarlayabilecek potansiyele dönüştüğüne vurgu yapmaktadır. $\mathrm{Bu}$ bağlamda geleceğin öğretmenlerinin matematik öğretiminde yaşadıkları kaygı düzeylerinin belirlenmesi amaçlanmaktadır. Ayrıca yaşanılan kaygının boyutunun belirlenmesi ve yorumlanmasının matematik öğretiminde var olan bu kaygının giderilmesine yönelik farklı stratejilerin geliştirilmesine katkı sağlayabilmesi bakımından araştırma önem arz etmektedir. Öğretmen adaylarının matematik öğretmeye yönelik kaygılarını belirleme, araştırmanın temel problemini oluşturmaktadır. Bu temel problem 1şı̆̆ında araştırmanın amacı matematik öğretmeni adaylarının matematik öğretme kaygı düzeylerini belirlemektir. Amaç doğrultusunda araştırmanın alt problemleri şu şekildedir:

- Matematik öğretmeni adaylarının matematiği öğretmeye yönelik kaygı düzeyleri nedir?

- Matematik öğretmeni adaylarının matematiği öğretmeye yönelik kayg1 düzeyleri öğrenim görülen lisans programına göre farklılaşmakta mıdır?

- Matematik öğretmeni adaylarının matematiği öğretmeye yönelik kaygı düzeyleri sınıf düzeyine göre farklılaşmakta mıdır?

- Matematik öğretmeni adaylarının matematiği öğretmeye yönelik kaygı düzeyleri cinsiyetlerine göre farklılaşmakta mıdır? 


\section{Yöntem}

\section{Araştırma Yöntemi}

Öğretmen adaylarının matematik öğretmeye yönelik kaygılarını belirlemek ve bu kaygıyı bazı değişkenlere göre farklılık gösterip göstermediğini ortaya koymak için çalışmada tarama yöntemi kullanılmıştır (McMillan \& Schumacher, 2010).

\section{Araştırma Grubu}

Araştırma Türkiye'de bulunan bir devlet üniversitesinin eğitim fakültesinde öğrenim gören ilköğretim ve ortaöğretim matematik öğretmeni adayları ile gerçekleştirilmiştir. Araştırma kolay ulaşılabilir örnekleme yöntemi ile seçilen 475 matematik öğretmeni adayı ile yürütülmüştür. Araştırmanın örneklemini ilköğretim matematik öğretmenliği programında öğrenim gören ve dört sınıftan oluşan 316 ilköğretim matematik öğretmeni adayı ve ortaöğretim matematik öğretmenliği programında öğrenim gören ve beş sınıftan oluşan 159 ortaöğretim matematik öğretmeni adayı oluşturmuştur. Örneklemde bulunan kız öğrencilerin sayısı 272, erkek öğrencilerin sayısı 203'tür.Araştırmaya katılan öğretmen adaylarının gönüllü olmaları dikkate alınmıştır.

\section{Veri Toplama Aracı}

Araştırmada matematik öğretmeni adaylarının lisans programı, cinsiyet ve sınıf ile ilgili bilgileri içeren kişisel bilgi formu ve matematiği öğretmeye yönelik kayg1 düzeylerini belirlemek için matematik öğretmeye yönelik kaygı ölçeği (Peker, 2006) kullanılmıştır. 23 maddeden oluşan 5'li likert tipi olan ölçeğin 4 alt boyutu vardır. Ölçekte bu alt boyutlar, alan bilgisinden (1-10), öz güvenden (11-16), matematiği öğretmeye yönelik tutumdan (17-20) ve alan eğitimi bilgisinden (21-23) kaynaklanan kayg1 olarak verilmiştir. Peker (2006) ölçeğin alt boyutlarındaki faktör yüklerini; alan bilgisinden kaynaklanan kaygı için 0,53 ile 0,86 arasında, öz güvenden kaynaklanan kaygı için 0.57 ile 0.76 arasında, matematiği öğretmeye yönelik tutumdan kaynaklanan kayg1 için 0.61 ile 0.70 arasında ve alan eğitimi bilgisinden kaynaklanan kaygı için 0.68 ile 0.78 arasında olduğunu belirtmiştir. Peker (2006) ölçeğin güvenirlik katsayısını 0.91, her bir alt boyut için hesaplanan güvenirlik katsayısını; alan bilgisinden kaynaklanan kayg1 alt boyutu için 0.90, öz güvenden kaynaklanan kayg1 alt boyutu için 0.83 , matematiği öğretmeye yönelik tutumdan kaynaklanan kaygı alt boyutu için 0.71 ve alan eğitimi bilgisinden kaynaklanan kaygı alt boyutu için 0.61 olarak hesaplamıştır. Ölçekte toplam puan ve her bir alt boyuttan alınan puanlar ayrı ayrı hesaplanabilmektedir. Matematik öğretmeye yönelik kaygı ölçeğinde yer alan maddelerin genel ortalama puan değeri 69 iken; alan bilgisinden, öz güvenden, matematik öğretmeye yönelik tutumdan ve alan eğitimi bilgisinden kaynaklanan kaygı alt boyutlarında ise sirasıyla 30, 18, 12 ve 9'dur. Ölçekte öğretmen adaylarının alacağı puanların yüksek olması matematik öğretmeye yönelik kaygılarının yüksek olduğuna işaret etmektedir. 


\section{Veri Analizi}

Verilerin analizinde 475 öğretmen adayına ait veri kullanılmıştır. Ölçekteki maddelere verilen yanıtlar; "tamamen katılıyorum", "katılıyorum", "kararsızım", "katılmıyorum", "hiç katılmıyorum" şeklindedir. Ölçeğe verilen yanıtların olumlu veya olumsuz olmaları dikkate alınarak puanlama yapılmış ve böylece öğretmen adaylarının toplam kaygı puanı oluşmuştur. Ölçekte yer alan 10 tane olumsuz maddede puanlama 5 (tamamen katılıyorum) den 1 (hiç katılmıyorum) e doğru; 13 tane olumlu maddede puanlama 1(tamamen katılıyorum) den 5 (hiç katılmıyorum) e doğru yapılarak bilgisayar ortamına aktarılmıştır. SPSS 16.0 paket programının kullanıldığı veri analizinde uygulanacak testi belirlemek amaciyla öncelikle verilerin normallik analizi yapılmıştır. Analiz yapılırken her bir ölçüme ait örneklem sayısının 29'dan fazla olduğu durumlarda Kolmogorov-Smirnov testi, 29'dan az olduğu durumlarda Shapiro-Wilk testi kullanılmıştır. Elde edilen p değerlerinin .05 ten büyük olması durumunda verilerin normal dağıldığı, küçük olması durumunda verilerin normal dağılmadığı göz önüne alınmıştır (Kalaycı, 2010).

Betimsel istatistiklerde aritmetik ortalama, ortanca, tepe değer ve standart sapma değerleri kullanılmıştır. Normallik varsayımlarının sağlandığı ölçümlerin analizinde bağımsız gruplar $\mathrm{t}$ testi ve tek yönlü varyans analizi yapılmıştır. Normallik varsayımlarının sağlanmadığı ölçümlerin analizinde ise Mann Whitney $U$ testi ve Kruskal Wallis testi gibi testler kullanılmıştır. Anlamlılık düzeyi olarak $\alpha=.05$ seçilmiştir.

\section{Bulgular}

$\mathrm{Bu}$ bölümde, verilerin analizi sonucu elde edilen bulgular araştırma problemlerine dayalı olarak sıralanmıştır.

\section{Matematik Öğretmeni Adaylarının Matematiği Öğretmeye Yönelik Kaygı Puanları}

Matematik öğretmeni adaylarının matematiği öğretmeye yönelik kayg1 puanlarına ilişkin betimsel istatistik sonuçları Tablo 1'de verilmiştir. 
Tablo 1

Öğretmen adaylarının matematiği öğretmeye yönelik kaygı puanları

\begin{tabular}{|c|c|c|c|c|c|c|c|c|}
\hline \multirow{11}{*}{ 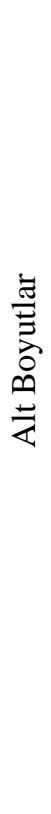 } & & Örneklem Türü & $n$ & $\bar{x}$ & SS & Ortanca & Min-Max & $\begin{array}{l}\text { Tepe } \\
\text { Değer }\end{array}$ \\
\hline & \multirow{2}{*}{ Alan bilgisi } & İlköğretim Matematik & 316 & 18.33 & 5.48 & 19.00 & $10.00-42.00$ & 20.00 \\
\hline & & Ortaöğretim Matematik & 159 & 19.27 & 5.80 & 20.00 & $10.00-40.00$ & 20.00 \\
\hline & \multirow{2}{*}{ Öz güven } & İlköğretim Matematik & 316 & 12.91 & 3.67 & 13.00 & $6.00-25.00$ & 12.00 \\
\hline & & Ortaöğretim Matematik & 159 & 13.63 & 3.51 & 13.00 & $6.00-24.00$ & 13.00 \\
\hline & \multirow{2}{*}{ Tutum } & İlköğretim Matematik & 316 & 6.83 & 2.18 & 7.00 & $4.00-18.00$ & 8.00 \\
\hline & & Ortaöğretim Matematik & 159 & 7.16 & 2.57 & 8.00 & $4.00-20.00$ & 8.00 \\
\hline & \multirow{2}{*}{$\begin{array}{l}\text { Alan eğitimi } \\
\text { bilgisi }\end{array}$} & İlköğretim Matematik & 316 & 5.76 & 1.82 & 6.00 & $3.00-15.00$ & 6.00 \\
\hline & & Ortaöğretim Matematik & 159 & 6.10 & 2.00 & 6.00 & $3.00-15.00$ & 6.00 \\
\hline & \multirow{2}{*}{ Genel kaygı } & İlköğretim Matematik & 316 & 43.85 & 10.79 & 45.00 & $23.00-85.00$ & 46.00 \\
\hline & & Ortaöğretim Matematik & 159 & 46.18 & 11.10 & 46.00 & $23.00-77.00$ & 46.00 \\
\hline
\end{tabular}

Tablo 1'e göre ilköğretim matematik öğretmeni adayları (İMÖ) ve ortaöğretim matematik öğretmen adaylarının (OMÖ) matematiği öğretmeye yönelik kaygı ölçeğinin geneline ilişkin puan ortalamaları dikkate alındığında $\left(\overline{\mathrm{x}}_{\text {IмӦ }}=43.85, \overline{\mathrm{x}}_{\text {омÖ }}=46.18\right)$ öğretmen adaylarının genel kaygılarının düşük olduğu söylenebilir. Ayrıca öğretmen adaylarının alan bilgisinden ( $\left.\overline{\mathrm{x}}_{\text {IMÖO }}=18.33, \overline{\mathrm{x}}_{\text {OMÖ }}=19.27\right)$, öz güvenden $\left(\overline{\mathrm{x}}_{\text {IMÖ }}=12.91\right.$, $\left.\overline{\mathrm{x}}_{\text {OMÖ }}=13.63\right)$, matematiği öğretmeye yönelik tutumdan $\left(\overline{\mathrm{x}}_{\text {IMÖ }}=6.83, \overline{\mathrm{x}}_{\text {OMÖ }}=7.16\right) \mathrm{ve}$ alan eğitimi bilgisinden $\left(\overline{\mathrm{x}}_{\text {IMÖ }}=5.76, \overline{\mathrm{x}}_{\text {OMÖ }}=6.10\right)$ kaynaklanan öğretme kaygıs1 boyutlarına ilişkin puan ortalamaları incelendiğinde kaygı düzeylerinin tüm alt boyutlarda da genel olarak düşük olduğu görülmektedir.

\section{Matematik Öğretmeni Adaylarının Matematiği Öğretmeye Yönelik Kaygı Puanlarının Öğrenim Görüllen Lisans Programına Göre Dağılımı}

Öğretmen adaylarının matematiği öğretmeye yönelik kaygı puanlarının öğrenim görülen lisans programına göre incelenmesine ilişkin Mann Whitney U-testi sonuçları Tablo 2'de sunulmuştur. 
Tablo 2

Öğretmen adaylarının matematiği ögretmeye yönelik kaygı puanlarının lisans programı türüne göre analizi

\begin{tabular}{|c|c|c|c|c|c|c|c|}
\hline & & Lisans Programı & $n$ & $\begin{array}{c}\text { Stra } \\
\text { Ortalamast }\end{array}$ & $\begin{array}{c}\text { Sira } \\
\text { Toplamı }\end{array}$ & $U$ & $p$ \\
\hline \multirow{10}{*}{ 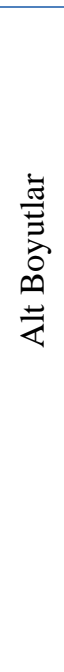 } & \multirow{2}{*}{ Alan bilgisi } & İlköğretim Matematik & 316 & 228.83 & 72311.00 & \multirow{2}{*}{22225.00} & \multirow{2}{*}{.040} \\
\hline & & Ortaöğretim Matematik & 159 & 256.22 & 40739.00 & & \\
\hline & \multirow{2}{*}{ Öz güven } & İlköğretim Matematik & 316 & 229.69 & 72582.50 & \multirow{2}{*}{22496.50} & \multirow{2}{*}{.061} \\
\hline & & Ortaöğretim Matematik & 159 & 254.51 & 40467.50 & & \\
\hline & \multirow{2}{*}{ Tutum } & İlköğretim Matematik & 316 & 233.41 & 73757.50 & \multirow{2}{*}{23671.50} & \multirow{2}{*}{.286} \\
\hline & & Ortaöğretim Matematik & 159 & 247.12 & 39292.50 & & \\
\hline & \multirow{2}{*}{$\begin{array}{l}\text { Alan eğitimi } \\
\text { bilgisi }\end{array}$} & İlköğretim Matematik & 316 & 231.08 & 73021.50 & \multirow{2}{*}{22935.50} & \multirow{2}{*}{.109} \\
\hline & & Ortaöğretim Matematik & 159 & 251.75 & 40028.50 & & \\
\hline & \multirow{2}{*}{ Genel kayg1 } & İlköğretim Matematik & 316 & 228.56 & 72224.50 & \multirow{2}{*}{22138.50} & \multirow{2}{*}{.034} \\
\hline & & Ortaöğretim Matematik & 159 & 256.76 & 40825.50 & & \\
\hline
\end{tabular}

Normallik analizinde sirasıyla alan bilgisi için $p_{\text {ilkmat }}<.05, p_{\text {omat }}<.05$; öz güven için $p_{\text {ilkmat }}<.05, p_{\text {omat }}<.05$, tutum için $p_{\text {ilkmat }}<.05, p_{\text {omat }}<.05$; alan eğitimi bilgisi için $p_{\text {ilkmat }}<.05, p_{\text {omat }}<.05$; genel kaygı için $p_{\text {ilkmat }}<.05$, $p_{\text {omat }}>$.05 bulunmuştur.

Tablo 2 incelendiğinde, öğrenim görülen lisans programına göre öğretmen adaylarının öz güvenden ( $U=22496.50, p>.05)$, matematiği öğretmeye yönelik tutumdan $(\mathrm{U}=23671.50, \mathrm{p}>.05)$ ve alan eğitimi bilgisinden $(\mathrm{U}=22935.50, \mathrm{p}>.05)$ kaynaklanan kaygı puanları arasında anlamlı fark olmadığı görülmektedir. Bununla birlikte öğrenim görülen lisans programına göre öğretmen adaylarının alan bilgisinden kaynaklanan kaygı $(U=22225.00, p<.05)$ ve matematiği öğretmeye yönelik genel kaygı ( $U=22138.50$, $\mathrm{p}<.05)$ puanları arasında anlamlı fark olduğu belirlenmiştir. Buna göre ilköğretim matematik öğretmeni adaylarının alan bilgisinden kaynaklanan kaygı ve matematiği öğretmeye yönelik genel kayg1 düzeylerinin ortaöğretim matematik öğretmeni adaylarına göre daha düşük olduğu söylenebilir.

\section{Matematik Öğretmeni Adaylarının Matematiği Öğretmeye Yönelik Kaygı Puanlarının Sınıf Düzeyine Göre Dağılımı}

İlköğretim matematik öğretmeni adaylarının matematiği öğretmeye yönelik kaygı puanlarının sınıf düzeyine göre incelemek için normallik analizi yapılmıştır. Analiz sonucunda sadece bazı ölçüm sonuçlarının ( $\mathrm{p}_{\text {sını2-alan bilgisi }}>.05, \mathrm{p}_{\text {sınıf-alanbilgisi }}>$.05, $\mathrm{p}_{\text {sınıf2-öz güven }}>.05$, $\mathrm{p}_{\text {sınıf2-genel kaygı }}>.05, \mathrm{p}_{\text {sınıf3-genel kaygl }}>.05$ ) normal dağılım gösterdiği tespit edilmiştir. Tüm ölçümler normal dağılım göstermediğinden ilköğretim matematik öğretmeni adaylarının matematiği öğretmeye yönelik kaygılarının sınıf düzeyine göre incelenmesinde Kruskal Wallis Testi kullanılmış ve test sonuçları Tablo 3'te sunulmuştur. 
Tablo 3

Illköğretim matematik ögretmeni adaylarının matematiği öğretmeye yönelik kaygı puanlarının sinıf düzeyine göre analizi

\begin{tabular}{|c|c|c|c|c|c|c|c|}
\hline & & Sinif & $n$ & Sira Ortalama & $S d$ & $\chi^{2}$ & $p$ \\
\hline \multirow{16}{*}{ 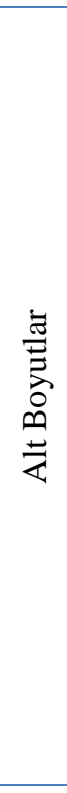 } & \multirow{4}{*}{ Alan bilgisi } & 1. & 97 & 156.89 & \multirow{4}{*}{3} & \multirow{4}{*}{1.100} & \multirow{4}{*}{.777} \\
\hline & & 2. & 66 & 158.93 & & & \\
\hline & & 3. & 76 & 151.72 & & & \\
\hline & & 4. & 77 & 166.84 & & & \\
\hline & \multirow{4}{*}{ Öz güven } & 1. & 97 & 164.08 & \multirow{4}{*}{3} & \multirow{4}{*}{.717} & \multirow{4}{*}{.869} \\
\hline & & 2. & 66 & 152.50 & & & \\
\hline & & 3. & 76 & 155.97 & & & \\
\hline & & 4. & 77 & 159.11 & & & \\
\hline & \multirow{4}{*}{ Tutum } & 1. & 97 & 152.22 & \multirow{4}{*}{3} & \multirow{4}{*}{2.236} & \multirow{4}{*}{.525} \\
\hline & & 2. & 66 & 156.80 & & & \\
\hline & & 3. & 76 & 171.29 & & & \\
\hline & & 4. & 77 & 155.25 & & & \\
\hline & \multirow{4}{*}{$\begin{array}{l}\text { Alan eğitimi } \\
\text { bilgisi }\end{array}$} & 1. & 97 & 173.91 & \multirow{4}{*}{3} & \multirow{4}{*}{11.771} & \multirow{4}{*}{.008} \\
\hline & & 2. & 66 & 139.73 & & & \\
\hline & & 3. & 76 & 139.50 & & & \\
\hline & & 4. & 77 & 173.93 & & & \\
\hline & \multirow{4}{*}{ Genel kaygı } & 1. & 97 & 160.52 & \multirow{4}{*}{3} & \multirow{4}{*}{.612} & \multirow{4}{*}{.894} \\
\hline & & 2. & 66 & 155.04 & & & \\
\hline & & 3. & 76 & 153.62 & & & \\
\hline & & 4. & 77 & 163.73 & & & \\
\hline
\end{tabular}

Tablo 3’te görüldüğü üzere, ilköğretim matematik öğretmeni adaylarının alan bilgisinden $\left(\chi^{2}(3)=1.100, p>.05\right)$, öz güvenden $\left(\chi^{2}(3)=.717, \quad \mathrm{p}>.05\right)$, matematiğ ögretmeye yönelik tutumdan $\left(\chi^{2}(3)=2.236, p>.05\right)$ kaynaklanan kayg1 ve matematiği öğretmeye yönelik genel kaygı $\left(\chi^{2}(3)=.612, p>.05\right)$ puanları arasında sınıf düzeyine göre anlamlı bir fark olmadığı belirlenmiştir. Bununla birlikte öğretmen adaylarının alan eğitimi bilgisinden $\left(\chi^{2}(3)=11.771, \mathrm{p}<.05\right)$ kaynaklanan öğretme kayg1 puanları arasında sınıf düzeyine göre anlamlı fark olduğu belirlenmiştir. İlköğretim matematik öğretmeni adaylarının alan eğitimi bilgisinden kaynaklanan öğretme kaygısının sıra ortalamaları dikkate alındığında; 2. ve 3. sınıftaki ilköğretim öğretmen adaylarının, 1. ve 4. sınıftaki öğretmen adaylarına göre alan eğitimi bilgisinden kaynaklanan kaygılarının daha düşük olduğu ifade edilebilir.

Ortaöğretim matematik öğretmeni adaylarının matematiği öğretmeye yönelik kaygı puanlarını sınıf düzeyine göre incelemek için öncelikle normallik analizi yapılmıştır. Analiz sonucunda sadece bazı ölçüm sonuçlarının ( $\mathrm{p}_{\text {sınıf2-alan bilgisi }}>$.05, $\mathrm{p}_{\text {sıııf3- }}$ alan bilgisi $>.05, \mathrm{p}_{\text {smıff-alan bilgisi }}>.05, \mathrm{p}_{\text {sınıf5-alan bilgisi }}>.05, \mathrm{p}_{\text {sınıf1-öz güven }}>.05, \mathrm{p}_{\text {sınıf3-öz güven }}>.05$, $\mathrm{p}_{\text {sınff5-alan eğitimi }}>$.05) normal dağılım gösterdiği tespit edilmiştir. Tüm ölçümler normal dağılım göstermediğinden ortaöğretim matematik öğretmeni adaylarının matematiği 
öğretmeye yönelik kaygılarının sınıf düzeyine göre incelenmesinde Kruskal Wallis Testi kullanılmış ve test sonuçları Tablo 4'te sunulmuştur.

Tablo 4

Ortaöğretim matematik ögretmeni adaylarının matematiği öğretmeye yönelik kaygl alt boyut puanlarının sinı düzeyine göre analizi

\begin{tabular}{lcccccc}
\hline Alt Boyutlar & Sinif & $n$ & Sira Ortalama & Sd & $\chi^{2}$ & $p$ \\
\hline \multirow{3}{*}{ Alan bilgisi } & 1. & 34 & 74.04 & & & \\
& 2. & 30 & 94.50 & 4 & 5.476 & .242 \\
& 3. & 40 & 82.29 & & & \\
Öz güven & 4. & 30 & 68.72 & & & \\
& 5. & 25 & 80.58 & & & \\
& 1. & 34 & 79.15 & & & \\
& 2. & 30 & 77.82 & 4 & & \\
& 3. & 40 & 89.81 & & & \\
Tutum & 4. & 30 & 69.38 & & & \\
& 5. & 25 & 80.82 & & & \\
& 1. & 34 & 77.19 & & & \\
& 2. & 30 & 89.20 & & & \\
& 3. & 40 & 82.65 & 4 & & \\
& 4. & 30 & 73.83 & & & \\
& 5. & 25 & 75.94 & & & \\
\hline
\end{tabular}

Tablo 4'e bakıldığında, ortaöğretim matematik öğretmeni adaylarının alan bilgisinden $\left(\chi^{2}(3)=5.476, p>.05\right)$, öz güvenden $\left(\chi^{2}(4)=3.548, p>.05\right)$, matematiğ $i$ öğretmeye yönelik tutumdan $\left(\chi^{2}(4)=2.350, p>.05\right)$ kaynaklanan öğretme kaygı puanları arasında sınıf düzeyine göre anlamlı bir fark olmadığı görülmektedir. Bununla birlikte ortaöğretim matematik öğretmeni adaylarının alan eğitimi bilgisinden $\left(\chi^{2}(4)=11.394\right.$, $\mathrm{p}<.05)$ kaynaklanan öğretme kaygı puanları arasında sınıf düzeyine göre anlamlı bir fark olduğu belirlenmiştir. Ortaöğretim matematik öğretmeni adaylarının alan eğitimi bilgisinden kaynaklanan öğretme kaygısı sıra ortalamaları dikkate alındığında; 1., 4. ve 5. sınıftaki ortaöğretim öğretmen adaylarının, 3. ve 2. sınıftaki öğretmen adaylarına göre alan eğitimi bilgisinden kaynaklanan öğretme kaygılarının daha düşük olduğu ifade edilebilir.

Ortaöğretim matematik öğretmeni adaylarının matematiği öğretmeye yönelik genel kaygı puanlarının sınıf düzeyine göre incelenmesine ilişkin ANOVA testi sonuçları Tablo 5’te sunulmuştur. 
Tablo 5

Ortaöğretim matematik öğretmeni adaylarının matematiği öğretmeye yönelik genel kaygı puanlarının sınıf düzeyine göre analizi

\begin{tabular}{llllll}
\hline Varyansin Kaynă̆ı & Kareler Toplamı & Sd & Kareler Ortalaması & $F$ & $p$ \\
\hline Gruplararası & 698.704 & 4 & 174.676 & & \\
Gruplariçi & 18787.007 & 154 & 121.994 & 1.432 & .226 \\
Toplam & 19485.711 & 158 & & & \\
\hline
\end{tabular}

Normallik analizi için $p_{\text {sinif1 }}>.05, p_{\text {sinf } 2}>.05, p_{\text {sinif }}>.05, p_{\text {sinif } 4}>.05, p_{\text {sinff }}>.05$ bulunmuştur.

Tablo 5 incelendiğinde, ortaöğretim matematik öğretmeni adaylarının matematiği öğretmeye yönelik genel kaygı puanlarının sınıf düzeyine göre anlamlı bir farklılık göstermediği tespit edilmiştir $\left(\mathrm{F}_{(4-154)}=1.432\right.$, $\left.\mathrm{p}>.05\right)$.

\section{Matematik Öğretmeni Adaylarının Matematiği Öğretmeye Yönelik Kaygı Puanlarının Cinsiyete Göre Dağılımı}

Öğretmen adaylarının matematiği öğretmeye yönelik kaygı alt boyut puanlarında cinsiyetlerine göre incelenmesine ilişkin Mann Whitney U testi sonuçları Tablo 6'da sunulmuştur.

Tablo 6

Matematik öğretmeni adaylarının matematiği ögretmeye yönelik kaygl alt boyut puanlarının cinsiyete göre analizi

\begin{tabular}{lllcccc}
\hline Alt Boyutlar & Cinsiyet & $n$ & $\begin{array}{c}\text { Sira } \\
\text { Ortalamast }\end{array}$ & Sira Toplamı & U & $p$ \\
\hline \multirow{2}{*}{ Alan bilgisi } & Kiz & 272 & 237.67 & 64647.50 & 27519.50 & .952 \\
& Erkek & 203 & 238.44 & 48402.50 & & \\
\multirow{2}{*}{ Öz güven } & Kiz & 272 & 248.38 & 67559.50 & 24784.50 & .055 \\
& Erkek & 203 & 224.09 & 45490.50 & & \\
\multirow{2}{*}{ Tutum } & Kiz & 272 & 238.25 & 64804.00 & & \\
& Erkek & 203 & 237.67 & 48246.00 & & .962 \\
\multirow{2}{*}{ Alan eğitimi bilgisi } & Kiz & 272 & 240.22 & 65340.50 & & \\
& Erkek & 203 & 235.02 & 47709.50 & 27003.50 & .673 \\
\hline
\end{tabular}

Normallik analizi için sırasıyla $p_{\mathrm{k} 1 \mathrm{z}}<.05, p_{\mathrm{erkek}}<.05, p_{\mathrm{k} 1 \mathrm{z}}<.05, p_{\text {erkek }}<.05, p_{\mathrm{k} 1 z}<.05$, $p_{\text {erkek }}<.05, p_{\mathrm{k} 1 \mathrm{z}}<.05, p_{\text {erkek }}<.05$ bulunmuştur.

Tablo 6 incelendiğinde, cinsiyete göre öğretmen adaylarının matematiği öğretmeye yönelik kaygıda alan bilgisinden $\left(U=27519.50, p^{>} .05\right)$, öz güvenden 
( $U=24784.50, p>.05)$, matematiği öğretmeye yönelik tutumdan $(U=27540.00, p>.05)$ ve alan eğitimi bilgisinden $(U=27003.50, p>.05)$ kaynaklanan öğretme kaygı puanları arasında anlamlı fark olmadığı belirlenmiştir.

Matematik öğretmeni adaylarının matematiği öğretmeye yönelik genel kayg1 puanları arasında cinsiyetlerine göre incelenmesine ilişkin bağımsız gruplar t testi sonuçları Tablo 7’de sunulmuştur.

Tablo 7

Matematik öğretmeni adaylarının matematiği öğretmeye yönelik genel kaygı puanlarının cinsiyete göre analizi

\begin{tabular}{lcccccc}
\hline Cinsiyet & $n$ & $\overline{\mathrm{x}}$ & $S$ & $S d$ & $t$ & $p$ \\
\hline Kiz & 85 & 44.83 & 10.89 & 473 & .476 & .634 \\
Erkek & 74 & 44.35 & 11.03 & & & \\
\hline
\end{tabular}

Normallik analizi için $p_{\mathrm{kzz}}>.05, p_{\text {erkek }}>.05$ bulunmuştur.

Tablo 7'de görüldüğü üzere, öğretmen adaylarının matematiği öğretmeye yönelik genel kaygı puanlarının cinsiyete göre anlamlı bir farklılık göstermediği tespit edilmiştir $\left(\mathrm{t}_{(473)}=.476, \mathrm{p}>.05\right)$.

\section{Sonuç ve Tartışma}

$\mathrm{Bu}$ araştırmada matematik öğretmeni adaylarının matematiği öğretmeye yönelik kaygı düzeyleri incelenmiş ve bu kaygının alan bilgisinden, öz güvenden, matematiği öğretmeye yönelik tutumdan ve alan eğitimi bilgisinden kaynaklanan öğretme kaygıs1 alt boyutları da ayrıntılı olarak betimlenmiştir. Araştırma bulgularına göre, matematik öğretmeni adaylarının matematiği öğretmeye yönelik genel kaygı düzeylerinin ortalama puan değerinin altında olduğundan matematiği öğretmeye yönelik genel kaygılarının düşük olduğu belirlenmiştir. Bunun nedenleri arasında matematik öğretmeni adaylarının kendilerini matematik öğretme konusunda her açıdan yeterli görmüş oldukları söylenebilir. Bekdemir (2007), ilköğretim matematik öğretmen adaylarındaki matematik kaygısının nedenlerinin araştırdığı çalışmasında ilköğretim öğretmen adaylarının az veya çok da olsa matematik kaygısına sahip olduklarını tespit etmiştir. Elmas (2010), sınıf öğretmeni adaylarının matematik öğretme kaygılarını incelediği çalışmasında öğretmen adaylarının matematik öğretme kaygılarının düşük olduğunu ifade etmiştir. Haciomeroglu (2014), ilköğretim matematik öğretmeni adaylarının matematik kaygıları ve matematik öğretme kaygıları arasındaki ilişkiyi incelediği araştırmasında öğretmen adaylarının matematik öğretme kaygılarının düşük düzeyde olduğunu belirlemiştir. Bu araştırmanın sonuçları Bekdemir (2007), Elmas (2010) ve Haciomeroglu (2014)'ün sonuçları ile paralellik göstermektedir. Matematik öğretmeni adaylarının matematiği öğretmeye yönelik kaygıları alt boyutlar açısından incelendiğinde; alan bilgisinden, öz güvenden, matematiği öğretmeye yönelik tutumdan ve alan eğitimi bilgisinden 
kaynaklanan öğretme kaygı düzeylerinin ortalama puan değerinin altında olduğu görülmüştür. Ancak öz güvenden kaynaklanan öğretme kaygı düzeylerinin diğer alt boyutlara göre ortalama puan değerine daha yakın olduğu gözlenmektedir. Araştırmada elde edilen bu sonuç Elmas (2010)'un sınıf öğretmeni adaylarının matematik öğretme kaygılarını incelediği araştırmanın bulgularıyla paralellik göstermektedir.

İlköğretim matematik öğretmeni adaylarının öz güvenden, matematiği öğretmeye yönelik tutumdan, alan eğitimi bilgisinden kaynaklanan öğretme kayg1 düzeylerinin ortaöğretim matematik öğretmeni adaylarıyla aynı düzeyde olduğu görülmektedir. Ancak ilköğretim matematik öğretmeni adaylarının alan bilgisinden kaynaklanan öğretme kaygısı ve matematiği öğretmeye yönelik genel kayg1 düzeylerinin ortaöğretim matematik öğretmeni adaylarına göre daha düşük kaygıda olduğu görülmüştür. İlköğretim matematik öğretmeni adaylarının bu alt boyutta düşük kaygıda olması ortaöğretim matematik öğretmeni adaylarına göre matematiği öğretmeye yönelik genel kaygı düzeyinde de farkın oluşmasına neden olmuş olabilir.

Ayrıca ilköğretim matematik öğretmeni adaylarının alan bilgisinden, öz güvenden, matematik öğretmeye yönelik tutumdan kaynaklanan öğretme kaygıları ve matematiği öğretmeye yönelik genel kaygı düzeyleri arasında sınıf düzeyine göre bir fark ortaya çıkmazken, öğretmen adaylarının alan eğitimi bilgisinden kaynaklanan öğretme kaygısında fark olduğu belirlenmiştir. Bu farkın lisans öğretimi boyunca alınan pedagojik derslerden kaynaklandığı şeklinde yorumlanabilir. Ortaöğretim matematik öğretmeni adaylarında ise alan bilgisinden, öz güvenden, matematiği öğretmeye yönelik tutumdan kaynaklanan öğretme kaygıları ve matematiği öğretmeye yönelik genel kayg1 düzeyleri arasında sınıf düzeyine göre bir fark ortaya çıkmazken, öğretmen adaylarının alan eğitimi bilgisinden kaynaklanan öğretme kaygılarında sınıf düzeyine göre fark olduğu belirlenmiştir. Birinci sınıfların öğretme kaygı düzeyinin düşük olmasından kaynaklanan bu farkın öğretmenlik uygulaması ve alan eğitimi gibi derslerle karşılaşılmadığından dolayı ortaya çıktığı şeklinde yorumlanabilir.

Matematik öğretmeni adaylarının alan bilgisinden, öz güvenden, matematiği öğretmeye yönelik tutumdan, alan eğitimi bilgisinden kaynaklanan öğretme kaygıları ve matematiği öğretmeye yönelik genel kaygı düzeyleri arasında cinsiyetlerine göre anlamlı bir fark ortaya çıkmamıştır. Elmas (2010) araştırmasında sınıf öğretmeni adaylarının matematik ögretme kaygılarında genel olarak cinsiyete göre anlamlı farklılık ortaya çıkmıştır. Kız öğretmen adaylarının matematik öğretme kaygı düzeyleri erkek öğretmen adaylarına göre daha yüksek olduğu sonucuna varmıştır. Akgün, Gönen ve Aydın (2007) tarafından yapılan çalışmada da fen bilgisi ve matematik öğretmeni adaylarının kaygı düzeylerinde her iki branştaki kız öğrencilerin erkek öğrencilere göre daha kaygılı olduğu belirlenmiştir. Aynı şekilde Eldemir (2006), sınıf öğretmeni adaylarının cinsiyet değişkeni ile matematik kaygı düzeyi arasında anlamlı bir farklılığın bulunduğunu ifade etmiştir. Kız öğretmen adaylarının erkek öğretmen adaylarına göre daha yüksek matematik kaygısı taşıdığını dile getirmiştir. Ancak bu araştırmada cinsiyete göre matematik öğretmeni adaylarının matematiği öğretmeye yönelik kaygılarının farklılık göstermediği ortaya çıkmıştır. Peker ve Halat (2008), sınıf 
öğretmeni adaylarının matematik öğretme kaygılarının cinsiyete göre farklılıklarını araştırdığı çalışmada cinsiyetin matematik öğretme kaygısında önemli bir etken olmadığını tespit etmişlerdir. Aynı şekilde Peker, Halat ve Mirasyedioğlu (2010)'da kız ve erkek öğretmen adaylarının matematik öğretme kaygı düzeylerinin farklılık göstermediğini belirlemişlerdir. Bu araştırmada elde edilen bulgu Peker ve Halat (2008) ve Peker, Halat ve Mirasyedioğlu (2010)'un elde ettikleri sonuçlarla paralellik göstermektedir.

Araştırma sonucunda şu önerilerde bulunulabilir; lisans dönemindeki öğretmenlik uygulamaları derslerinin uygulama saatleri arttırılabilir ve böylece öğretmen adaylarının matematik öğretme deneyimlerinin daha fazla olması sağlanabilir. $\mathrm{Bu}$ sayede öğretme kaygısına sahip öğretmen adaylarının kaygılarının azalması söz konusu olabilir. Matematiği öğretmeye yönelik kaygıda öğretmen adaylarının genel kaygı düzeylerinin öğrenim görülen lisans programına göre farklılaştığı görüldüğünden bundan sonra yapılacak nitel araştırmalarla ilköğretim ve ortaöğretimde yaşanabilecek öğretme kaygısının nedenleri daha ayrıntılı bir şekilde araştırılması önerilebilir. Ayrıca yapılacak yeni araştırmalarda farklı üniversitelerden örneklemler seçilerek karşılaştırmalar yapılabilir.

\section{Kaynakça}

Akgün, A., Gönen, S., \& Aydın, M. (2007). İlköğretim fen ve matematik öğretmenliği öğrencilerinin kaygı düzeylerinin bazı değişkenlere göre incelenmesi. Elektronik Sosyal Bilimler Dergisi, 6(20), 283-299.

Aydın, B. (2011). İlköğretim ikinci kademe düzeyinde matematik kaygısının cinsiyete göre farklılıkları üzerine bir çalışma. Kastamonu Ĕ̆itim Dergisi, 19(3), 1029-1036.

Baloğlu, M. (2001). Matematik korkusunu yenmek. Kuram ve Uygulamada Ĕgitim Bilimleri, 1(1), 59-76.

Baloğlu, M., \& Koçak, R. (2006). A multivariate investigation of the di mathematics anxiety. Personality and Individual Differences, 40, 1325-1335.

fferences in

Battista, M. T. (1986). The relationship of mathematics anxiety and mathematical knowledge to the learning of mathematical pedagogy by preservice elementary teachers. School Science and Mathematics, 86(1), 10-19. doi: 10.1111/j.19498594.1986.tb11580.x

Bekdemir, M. (2007). İlköğretim matematik öğretmen adaylarındaki matematik kaygısının nedenleri ve azaltılması için öneriler (Erzincan Eğitim Fakültesi Örneği). Erzincan Ĕ̈itim Fakültesi Dergisi, 9(2), 131-144.

Bekdemir, M. (2010). The pre-service teachers' mathematics anxiety related to depth of negative experiences in mathematics classroom while they were students. Educational Studies in Mathematics, 75(3), 311-328. doi: 10.1007/s10649-0109260-7

Brady, P., \& Bowd, A. (2005). Mathematics anxiety, prior experience and confidence to teach mathematics among pre-service education students. Teachers and Teaching: Theory and Practice, 11(1), 37-46. 
Brown, A. B., Westenskow, A., \& Moyer-Packenham, P. S. (2011). Elementary preservice teachers can they experience mathematics teaching anxiety without having mathematics anxiety? IUMPST: The Journal, 5, 1-14.

Byrd, P. G. (1982). A descriptive study of mathematics anxiety: its nature and antecedents (Unpublished doctoral dissertation). Indiana University.

Dreger, R. M., \& Aiken, L. R. (1957). The identification of number anxiety in a college population. Journal of Educational Psychology, 48(6), 344-351.

Eldemir, H. H. (2006). Sinıf ögretmeni adaylarının matematik kaygısının bazı psikososyal değişkenler açısından değerlendirilmesi (Yayımlanmamış Yüksek Lisans Tezi). Cumhuriyet Üniversitesi, Sivas.

Elmas, S. H. (2010). Sinıf öğretmeni adaylarının matematik öğretmeye yönelik kaygı düzeyleri ve bu kaygıya neden olan faktörler (Yayınlanmamış Yüksek Lisans Tezi). Afyon Kocatepe Üniversitesi, Sosyal Bilimler Enstitüsü, Afyon.

Gresham, G. (2007). A study of mathematics anxiety in pre-service teachers. Early Childhood Education Journal, 35(2), 181-188. doi: 10.1007/s10643-007-0174-7

Gresham, G. (2010). A study exploring exceptional education pre-service teachers' mathematics anxiety. IUMPST: The Journal, 4, 1-14.

Haciomeroglu, G. (2014). Elementary pre-service teachers' mathematics anxiety and mathematics teaching anxiety. International Journal for Mathematics Teaching and Learning,1-10.ISSN: 1473-0111

Hadley, K. M., \& Dorward, J. (2011). The relationship among elementary teachers' mathematics anxiety, mathematics instructional practices, and student mathematics achievement. Journal of Curriculum and Instruction (JoCI), 5(2), 27-44.

Jackson, E. (2008). Mathematics anxiety in student teachers. Practitioner Research in Higher Education, 2(1), 36-42.

Kalayc1, Ş. (Edt.) (2010). SPSS uygulamalı çok değişkenli istatistik teknikleri (5.Bask1). Ankara: Asil Yayın Dağıtım.

Liu, F. (2008). Impact of online discussion on elementary teacher candidates' anxiety towards teaching mathematics. Education, 128(4), 614-629.

Ma, X. \& Xu, J. (2004). The causal ordering of mathematics anxiety and mathematics achievement: A longitudinal panel analysis. Journal of Adolescence, 27, 165-179.

McMillan, J. H., \& Schumacher, S. (2010). Research in education: Evidence-based inquiry (7th ed.). Boston: Pearson.

Peker, M. (2006). Matematik öğretimine yönelik kaygı ölçeğinin geliştirilmesi. Eğitim Bilimleri ve Uygulama Dergisi, 5(9), 73-92.

Peker, M. (2008). Eğitim Programları ve Öğretmen Adaylarının Matematik Öğretme Kaygısı. VIII. Ulusal Fen Bilimleri ve Matematik Eğitimi Kongresi, 27-29 Ağustos 2008, Abant İzzet Baysal Üniversitesi, Bolu. 
Peker, M. (2009a). The use of expanded microteaching for reducing pre-service teachers' teaching anxiety about mathematics. Scientific Research and Essay, 4(9), 872-880.

Peker, M. (2009b). Pre-service teachers' teaching anxiety about mathematics and their learning styles. Eurasia Journal of Mathematics, Science \& Technology Education, 5(4), 335-345.

Peker, M. (2009c). The effects of an instruction using problem solving strategies in Mathematics on the teaching anxiety level of the pre-service primary school teachers. The New Educational Review, 19(3-4), 95-114.

Peker, M. (2015). The relationship between mathematics teaching anxiety and selfefficacy beliefs toward mathematics teaching. International Conference on Social Sciences and Education Research 29-31 October, Antalya-Turkey.

Peker, M., \& Halat, E. (2008). The pre-service elementary school teachers' mathematics teaching anxiety and gender. The European Conference on Educational Research, 10-12 September, Goteborg, Sweden.

Peker, M., \& Halat, E. (2009). Teaching anxiety and the mathematical representations developed through Web Quest and spreadsheet activities. Journal of Applied Sciences, 9(7), 1301-1308. ISSN: 1812-5654

Peker, M., Halat, E., \& Mirasyedioğlu, Ş. (2010). Gender related differences in mathematics teaching anxiety. The Mathematics Educator,12(2), 125-140.

Satake, E., \& Amato, P. P. (1995). Mathematics anxiety and achievement among Japanese elementary school students. Educational and Psychological Measurement, 55(6), 1000-1007. doi:10.1177/0013164495055006009

Sherman, B. F., \& Wither, D. P. (2003). Mathematics anxiety and mathematics achievement. Mathematics Education Research Journal, 15(2), 138-150.

Tooke, J., \& Lindstrom, L. C. (1998). Effectiveness of a mathematics methods course in reducing math anxiety of preservice elementary teachers. School Science and Mathematics, 98(3), 136-139.

Ural, A. (2015). Matematik öz yeterlik algısının matematik öğretmeye yönelik kaygıya etkisi. Kuramsal Eğitim Bilim Dergisi, 8(2), 173-184.

Uusimaki, L., \& Nason, R. (2004). Causes underlying pre-service teachers' negative beliefs and anxieties about mathematics. Proceedings of the 28th Conference of the International Group for the Psychology of Mathematics Education, 4, 369-376.

Vinson, B. M. (2001). A comparison of preservice teachers' mathematics anxiety before and after a methods class emphasizing manipulatives. Early Childhood Education Journal, 29(2), 89-94.

Zakaria, E., \& Nordin, M. N. (2008). The effects of mathematics anxiety on matriculation students as related to motivation and achievement. Eurasia Journal of Mathematics, Science \& Technology Education, 4(1), 27-30 